\title{
Clinical Analysis of Pulmonary Tuberculosis in Association with Corticosteroid Therapy
}

\author{
Yoshihiro Kobashi and Toshiharu Matsushima*
}

\begin{abstract}
Objective Due to the increased incidence of pulmonary tuberculosis in association with corticosteroid therapy during the last five years in our associated hospitals, we studied the clinical characteristics of these patients.

Patients Fourteen cases of pulmonary tuberculosis were collected which occurred in association with corticosteroid drugs in our associated hospitals during the last 10 years; four patients (2.1\%) from April 1991 to March 1996 and 10 patients (4.3\%) from April 1996 to March 2001.

Results The average age of the 14 patients was 74.1 years old and the male:female ratio was 9:5. Regarding underlying diseases, respiratory diseases ( 7 patients) were the most frequent and a past history of pulmonary tuberculosis was recognized in six patients. The duration of corticosteroid administration ranged from two months to seven years and the total dose of corticosteroids ranged from 1.20 $\mathrm{g}$ to $12.05 \mathrm{~g}$. Pulmonary tuberculosis was detected by chance during a health examination in eight patients and radiological findings showed an infiltration shadow without cavity located in a portion other than the predominant location in four patients. A microbiological examination was smear positive in eight patients but tolerance was not shown to any antituberculous drugs. The prognosis was poor because the mortality rate was high, but the cause of death was not related to the progress of pulmonary tuberculosis.

Conclusion Careful observation of patients is considered to be important because pulmonary tuberculosis in association with corticosteroid drugs was found among inpatients, there was no relationship to the total dose or duration of administration of corticosteroid drugs, there were no clinical symptoms, and the patients exhibited atypical radiographic findings.

(Internal Medicine 41: 1103-1110, 2002)
\end{abstract}

Key words: pulmonary tuberculosis, corticosteroid drug, inpatients

\section{Introduction}

Corticosteroid drugs are a well-known risk factor for tuberculosis but the accurate morbidity of tuberculosis due to these drugs is still unknown (1). Regarding the pharmacological mechanism, the morbidity of tuberculosis is thought to have increased because the tuberculin reaction is markedly decreased when corticosteroid drugs are administered at over $15 \mathrm{mg} /$ day for a few weeks (1).

Because we often had many patients with pulmonary tuberculosis of over one month's duration in association hospitals during the last 10 years, we decided to carry out a clinical analysis of pulmonary tuberculosis with regard to the number of patients with a history of corticosteroid administration and the patient's underlying diseases.

\section{Patients and Methods}

The object of this study was to select only patients who had received over $20 \mathrm{mg} /$ day of corticosteroid drugs for over one month. Corticosteroid drugs were administered to 261 inpatients and pulmonary tuberculosis was found in four patients (1.4\%) between April 1991 and March 1996. Between April 1996 and March 2001, these drugs were given to 348 patients and pulmonary tuberculosis was found in 10 patients $(2.9 \%)$ at Kawasaki Medical School Hospital, Kawasaki Medical School Kawasaki Hospital and Asahigaoka Hospital in Kurashiki and Okayama, Japan. We studied the clinical characteristics of these patients, their backgrounds (age, sex, underlying disease, past history, etc.), the methods by which the disease was detected clinical symptoms, main laboratory findings, radiological findings according to the classification of the Japanese Society for Tuberculosis, the duration of administration of corticosteroid drugs, the total dose of these drugs, the antituberculous treatment performed for pulmonary tuberculosis, the prognosis and the outcome for these 14 patients.

In addition, the interval of administration of corticosteroid drugs was adjusted to the interval from the initiation of these drugs to the interval from the initiation of these drugs to the

From the Division of Respiratory Diseases, Department of Medicine, Kawasaki Medical School Kawasaki Hospital, Okayama and *the Division of Respiratory Diseases, Department of Medicine, Kawasaki Medical School, Kurashiki

Received for publication February 19, 2002; Accepted for publication August 15, 2002

Riprint requests should be addressed to Dr. Yoshihiro Kobashi, the Division of Respiratory Diseases, Department of Medicine, Kawasaki Medical School Kawasaki Hospital, 2-1-80 Nakasange, Okayama 700-8505 
initiation of antituberculous treatment. The total dose of corticosteroid drugs was calibrated to the dose of prednisolone containing both intraoral and intravenous drugs with the exception of prednisolone.

\section{Statistical analysis}

Significant differences in clinical parameters were evaluated by the Student t-test. A p-value of less than 0.05 was considered statistically significant.

\section{Results}

The underlying diseases of patients who received over 20 $\mathrm{mg}$ /day of corticosteroid drugs for over one month during both periods are shown in Table 1 . Among the 267 patients who received corticosteroid drugs between 1991 and 1996, bronchial asthma was the most frequent underlying disease among respiratory diseases in 75 patients, idiopathic pulmonary fibrosis was second in 48 patients and eosinophilic pneumonia was third in 19 patients. The most frequent non-respiratory disease was found in 52 patients. Among the 348 inpatients who received corticosteroid drugs between 1996 and 2001, the most frequent underlying respiratory disease was bronchial asthma in 99 patients, second was idiopathic pulmonary fibrosis in 70 patients, and third was interstitial pneumonia associated with collagen vascular disease in 28 patients. The most frequent nonrespiratory disease was collagen disease in 25 patients. Diabetes mellitus was found in 81 patients.

The background of the 14 patients (4 patients in 1991-1996 and 10 patients in 1996-2001) who appeared to fulfill the cri- teria for this study is shown in Table 2. The patients (eight males and six females) ranged in age from 47 to 85 years old (mean age: 74.1 ) and 12 of them were considered as elderly, being over 65 years old. The underlying diseases in these patients were as follows; seven patients had idiopathic pulmonary fibrosis (IPF), three had collagen diseases (one had rheumatoid arthritis, one had polyarteritis nodosa, and one had dermatomyositis), three had hematological diseases (one had idiopathic thrombocytopenic purpura, one had mycosis fungoides, and one had autoimmune hemolytic anemia), and one had rapidly progressive glomerulonephritis + pulmonary bleeding. As for other complications, four patients had rapidly diabetes mellitus, three had chronic renal disease, two had chronic hepatic disease, and two had a malignant disease. Although a comparison of both periods showed a slight increase in the number of patients with IPF (from $2.1 \%$ to $8.6 \%$ ) and patients with diabetes mellitus (from $1.9 \%$ to $3.7 \%$ ), there was no significant proportional difference between the two groups. Six patients (42.9\%) had a history of pulmonary tuberculosis and their chest $\mathrm{X}$-ray findings before the initiation of corticosteroid drugs were all type IV or V in the classification of the Japanese Society for Tuberculosis. Purified protein derivative (PPD) before the diagnosis of pulmonary tuberculosis was positive in only 1 of 10 patients (10\%).

The treatment with corticosteroid drugs, which included other immunosuppressive drugs and preventive isoniazid (INH) is shown in Table 3. Although the initial dose of corticosteroid drugs ranged from 10 to $60 \mathrm{mg} /$ day, the dose was decreased to from 5 to $40 \mathrm{mg} /$ day when pulmonary tuberculosis ranged from two months to seven years at maximum. The total dose of cor-

Table 1. Underlying Diseases of Inpatients Administered Corticosteroid Drugs for Over One Month

\begin{tabular}{lrlr}
\hline \multicolumn{2}{c}{ April 1991 March 1996 (267 cases) } & \multicolumn{2}{c}{ April 1996 March 2001 (348 cases) } \\
\hline Respiratory disease & 218 & Respiratory disease & 304 \\
Bronchial asthma & 75 & Bronchial asthma & 99 \\
IPF & 48 & IPF & 70 \\
Eosinophilic pneumonia & 19 & CVD-IP & 28 \\
CVD-IP & 18 & Drug-induced pneumonia & 20 \\
Drug-induced pneumonia & 12 & Lung cancer & 20 \\
Organizing pneumonia & 11 & Eosinophilic pneumonia & 16 \\
Lung cancer & 11 & Organizing pneumonia & 15 \\
Hypersensitivity pneumonitis & 7 & Radiation pneumonitis & 13 \\
Radiation pneumonitis & 6 & Hypersensitivity pneumonitis & 8 \\
Sarcoidosis & 3 & Sarcoidosis & 5 \\
Others & 8 & ABPA & 3 \\
Non-respiratory disease & 49 & Others & 7 \\
Collagen disease & 30 & Non-respiratory disease & 44 \\
Pemphigoid vulgaris & 5 & Collagen disease & 25 \\
Renal disease & 5 & Polymyalgia rheumatica & 7 \\
Neurological disease & 3 & Pemphigoid vulgaris & 4 \\
Leukemia & 2 & Multiple myeloma & 2 \\
Others & 4 & Others & 6 \\
& & &
\end{tabular}

IPF: Idiopathic pulmonary fibrosis, CVD-IP: Interstitial pneumonia associated with collagen vascular disease, ABPA: Allergic bronchopulmonary aspergillosis. 


\section{Pulmonary Tuberculosis in Association with Corticosteroid Drugs}

Table 2. Background (14 Cases)

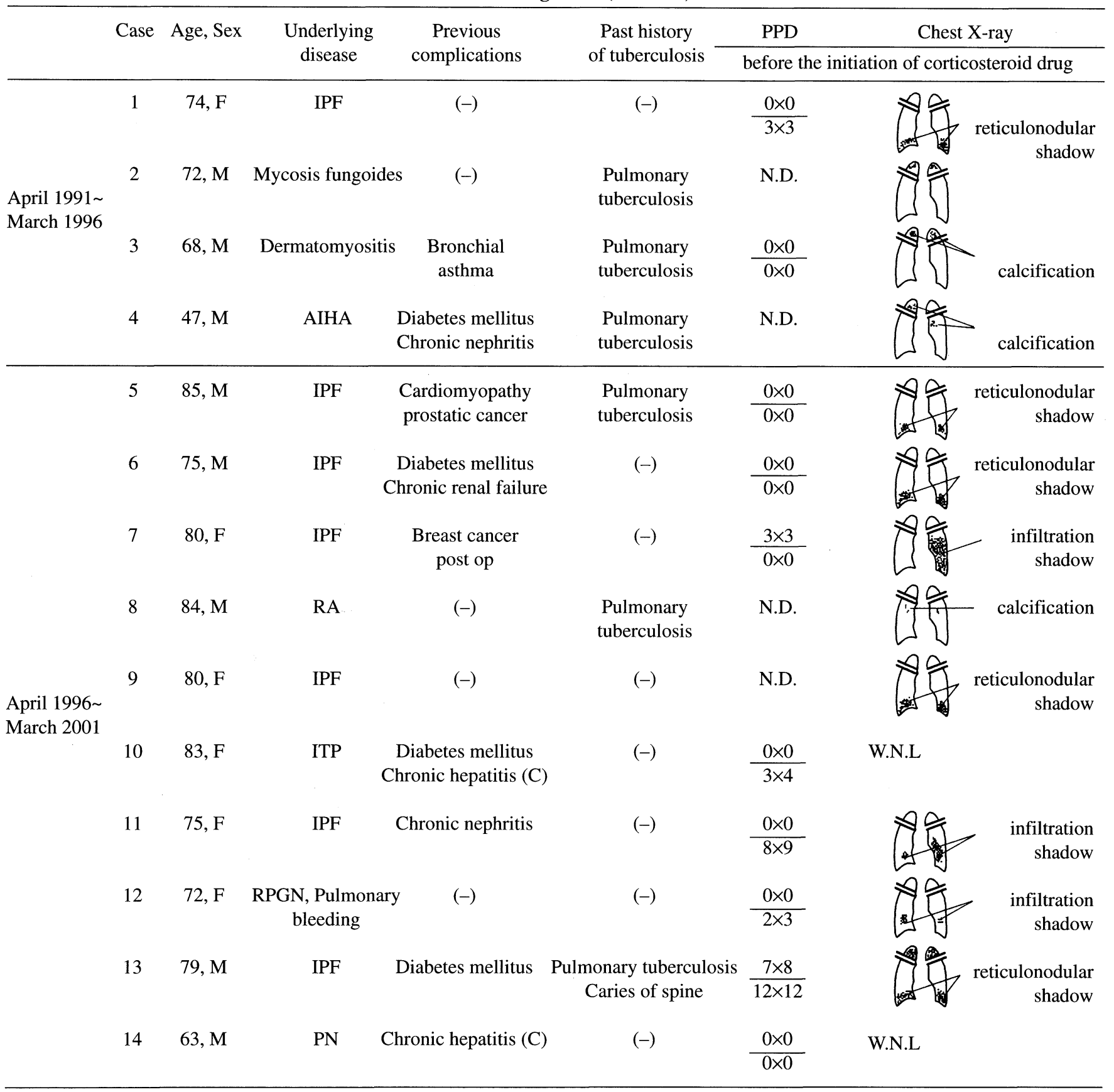

IPF: Idiopathic pulmonary fibrosis, RA: Rheumatoid arthritis, PN: Polyarteritis nodosa, RPGN: Rapidly progressive glomerulonephritis, AIHA: Autoimmune hemolytic anemia, N.D.: Not done, W.N.L: Within normal limit, PPD: Purified protein derivative.

ticosteroid drugs ranged from 1.16 to $12.05 \mathrm{~g}$ calibrated to prednisolone. A combination of other immunosuppressive drugs excluding corticosteroid drugs was employed in three patients who were all given cyclophosphamide $50 \mathrm{mg} /$ day for from 14 days to 6 months. Although preventive INH was carried out in 62 patients for from two to six months, pulmonary tuberculosis appeared in two patients (3.2\%) after administration of INH for two months immediately after the initiation of corticosteroid drugs was stopped.
The clinical findings at the onset of pulmonary tuberculosis are shown in Table 4 and 5. The disease was detected in eight patients by a chest X-ray during the follow-up of an underlying disease and in six patients from clinical symptoms. The main laboratory findings were as follows; leukocytosis in 7 , elevation of C-reactive protein in 12, an increase in the erythrocyte sedimentation rate in 12 as an inflammatory reaction, a decrease in total protein in 10 , in serum albumin in 9 , and in serum globulin in 4 as a nutritional condition. PPD was per- 


\section{KoBASHI and MATSUSHIMA}

Table 3. Treatment Content of Corticosteroid Drug

\begin{tabular}{|c|c|c|c|c|c|c|c|}
\hline & \multirow[b]{2}{*}{ Case } & \multicolumn{4}{|c|}{ Corticosteroid treatment administered until the diagnosis of pulmonary tuberculosis } & \multirow{2}{*}{$\begin{array}{c}\text { Other } \\
\text { immunosuppressive } \\
\text { drug }\end{array}$} & \multirow{2}{*}{$\begin{array}{l}\text { Preventive } \\
\text { INH }\end{array}$} \\
\hline & & Initiation dose & Dose of onset & $\begin{array}{c}\text { Interval of } \\
\text { administration }\end{array}$ & Total dose & & \\
\hline \multirow{4}{*}{$\begin{array}{l}\text { April 1991 } \\
\text { March } 1996\end{array}$} & 1 & $20 \mathrm{mg} / \mathrm{day}$ & $10 \mathrm{mg} /$ day & 2.5 months & $1.16 \mathrm{~g}$ & $(-)$ & $(-)$ \\
\hline & 2 & $60 \mathrm{mg} /$ day & $15 \mathrm{mg} /$ day & 2 months & $1.24 \mathrm{~g}$ & $(-)$ & $(-)$ \\
\hline & 3 & $40 \mathrm{mg} /$ day & $20 \mathrm{mg} /$ day & 3 months & $2.50 \mathrm{~g}$ & $(-)$ & $(-)$ \\
\hline & 4 & $40 \mathrm{mg} /$ day & $5 \mathrm{mg} /$ day & 6 months & $3.30 \mathrm{~g}$ & $(-)$ & $(-)$ \\
\hline \multirow{10}{*}{$\begin{array}{l}\text { April 1996 } \\
\text { March 2001 }\end{array}$} & 5 & $30 \mathrm{mg} /$ day & $7.5 \mathrm{mg} /$ day & 3 months & $1.95 \mathrm{~g}$ & $(-)$ & $(-)$ \\
\hline & 6 & $\begin{array}{l}\text { Pulse } 1 \mathrm{~g} / \text { day } \times 3 \\
+30 \mathrm{mg} / \text { day }\end{array}$ & $10 \mathrm{mg} /$ day & 4.5 months & $4.56 \mathrm{~g}$ & $(-)$ & $(-)$ \\
\hline & 7 & $30 \mathrm{mg} / \mathrm{day}$ & $10 \mathrm{mg} /$ day & 2 months & $1.20 \mathrm{~g}$ & $(-)$ & $(-)$ \\
\hline & 8 & $10 \mathrm{mg} /$ day & $5 \mathrm{mg} /$ day & 7 years & $12.05 \mathrm{~g}$ & $(-)$ & $(-)$ \\
\hline & 9 & Pulse 1g/day $\times 3$ & $15 \mathrm{mg} / \mathrm{day}$ & 3 months & $5.12 \mathrm{~g}$ & $(-)$ & $(-)$ \\
\hline & 10 & $\begin{array}{l}+60 \mathrm{mg} / \text { day } \\
50 \mathrm{mg} / \text { day }\end{array}$ & 30 mg/day & 22 months & $9.45 \mathrm{~g}$ & $(-)$ & $(-)$ \\
\hline & 11 & 40 mg/day & $10 \mathrm{mg} /$ day & 3 years & $8.50 \mathrm{~g}$ & $\begin{array}{l}\text { Cyclophosphamide } \\
50 \mathrm{mg} \text { ( } 6 \text { months) }\end{array}$ & $(-)$ \\
\hline & 12 & $40 \mathrm{mg} /$ day & $10 \mathrm{mg} /$ day & 5.5 months & $5.31 \mathrm{~g}$ & $(-)$ & $\begin{array}{c}(+) \\
0.3 \text { g/day } \\
(2 \text { months })\end{array}$ \\
\hline & 13 & $20 \mathrm{mg} /$ day & $10 \mathrm{mg} /$ day & 9.5 months & $3.15 \mathrm{~g}$ & $\begin{array}{l}\text { Cyclophosphamide } \\
50 \mathrm{mg} \text { (5 months) }\end{array}$ & $\begin{array}{c}(+) \\
0.3 \text { g/day } \\
(2 \text { months })\end{array}$ \\
\hline & 14 & $60 \mathrm{mg} / \mathrm{day}$ & $40 \mathrm{mg} / \mathrm{day}$ & 3 months & $5.60 \mathrm{~g}$ & $\begin{array}{l}\text { Cyclophosphamide } \\
50 \mathrm{mg} \text { (14 days) }\end{array}$ & $(-)$ \\
\hline
\end{tabular}

formed for 13 patients and was positive in 8 of those patients (61.5\%). Among 10 patients in whom the PPD was performed before the initiation of corticosteroid drugs, it converted to positive in six, to negative in one and it remained negative in three. Concerning radiological findings, abnormal shadows were recognized as infiltration opacities without cavity in 11 of the 14 patients. They were located in the predominant location (S1, S2, S6) in 10 patients and were diagnosed as lower lung field tuberculosis in the remaining four patients. The distribution of lesions was bilateral in four, on the right in four, and on the left in six. The extension of lesions was restricted to the unilateral lung field with the exception of one patient. The microbiological examination for Mycobacterium tuberculosis was smear positive, culture positive in eight patients and smear negative, culture positive in six patients, but none of the strains of Mycobacterium tuberculosis had tolerance for all antituberculous drugs. A transbronchial lung biopsy (TBLB) was performed on three patients with smear negative results on the microbiological examination, and a caseating epitheloid granu- loma including acid-fast bacilli was recognized in all three patients on a histological examination.

The treatment of pulmonary tuberculosis with antituberculous drugs and the outcome are shown in Table 6. Treatment with antituberculous drugs (INH+RFP+SM or INH+RFP+EB) was carried out for 13 patients. One of the 14 patients died before the diagnosis of pulmonary tuberculosis was obtained. Twelve patients were converted to acid-fast bacilli negative within two months. The remaining patient died three weeks after the initiation of antituberculous drugs. The final outcome obtained was clinical improvement (decrease in abnormal shadows on chest X-rays) in eight patients (57.1\%), but death for the remaining six patients. The causes were complicated nosocomial pneumonia due to MRSA and/or Pseudomonas aeruginosa in two patients, respiratory failure due to acute transformation of interstitial pneumonia in two, sepsis from a urinary tract infection due to Enterococcus faecalis in one, and worsening of mycosis fungoides in one. Corticosteroid drugs were administered for underlying diseases during the treatment 
Pulmonary Tuberculosis in Association with Corticosteroid Drugs

Table 4. Clinical Findings at the Onset of Pulmonary Tuberculosis (1)

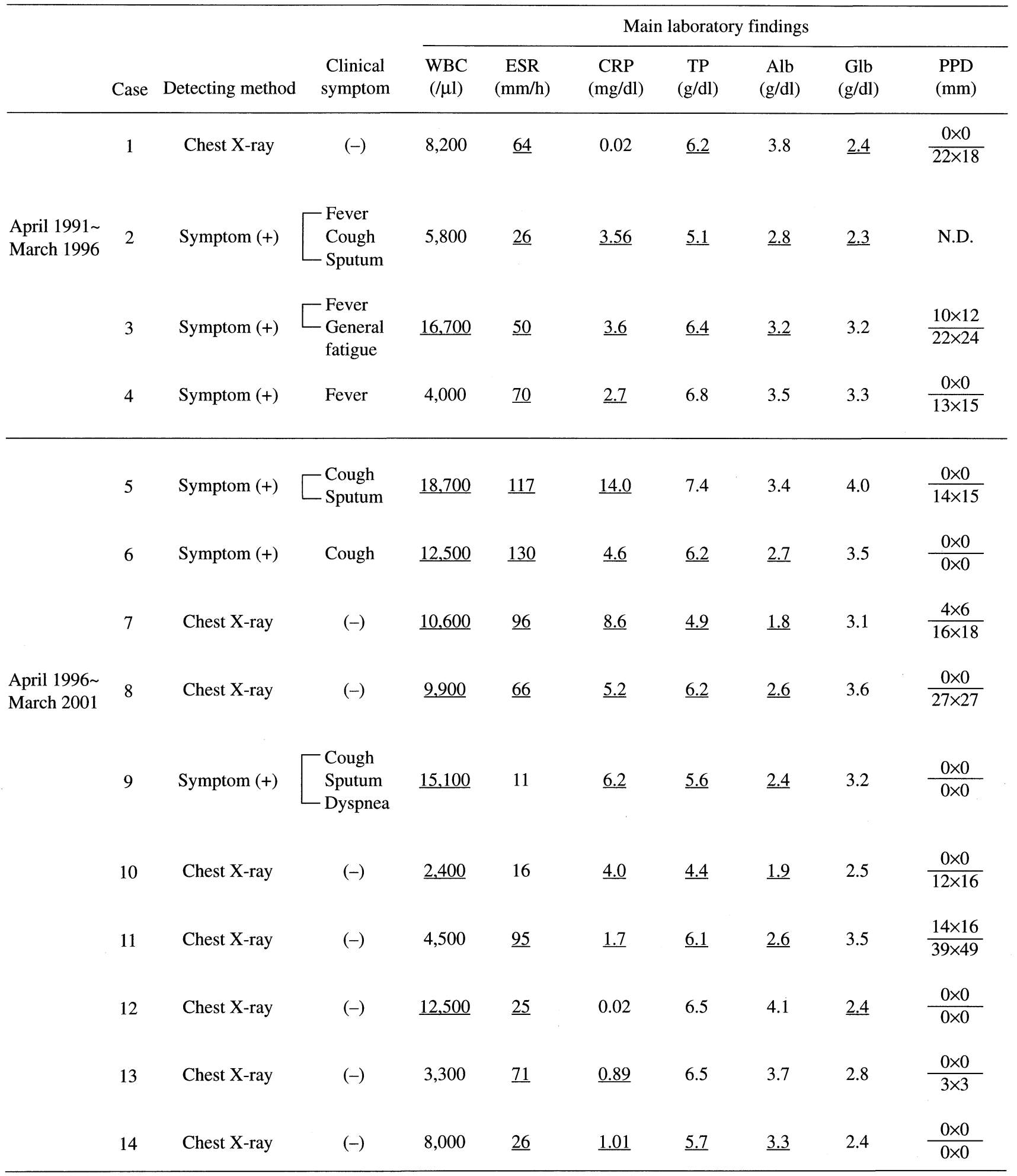

WBC: White blood cell, ESR: Erythrocyte sedimentation rate, CRP: C reactive protein, TP: Total protein, Alb: Albumin, Glb: Globulin, PPD: Purified protein derivative, N.D.: Not done.

with antituberculous drugs with the exception of one patient in five, and it was increased in three because of worsening of with sepsis from a urinary tract infection. The dose of corticos- the underlying disease.

teroid drugs was decreased in five patients, no change was noted 
Table 5. Clinical Findings at the Onset of Pulmonaly Tuberculosis (2)

\begin{tabular}{|c|c|c|c|c|c|c|}
\hline & \multirow{2}{*}{ Case } & \multirow{2}{*}{$\begin{array}{l}\text { Chest X-ray finding } \\
\text { (Nippon Kekkakubyo Gakkai) }\end{array}$} & \multicolumn{3}{|c|}{ Microbiological examination } & \multirow{2}{*}{$\begin{array}{l}\text { Histological examination } \\
\text { (Caseating epitheloid } \\
\text { granuloma) }\end{array}$} \\
\hline & & & Smear & Culture & Tolerance test & \\
\hline \multirow{4}{*}{$\begin{array}{l}\text { April 1991 } \\
\text { March 1996 }\end{array}$} & 1 & ${ }_{1} \mathrm{III}_{2}\left(\mathrm{lt} \mathrm{s}_{1+2}\right)$ & $(-)$ & (+) (5w, 3 colony) & $(-)$ & $(+)$ \\
\hline & 2 & ${ }_{\mathrm{I}} \mathrm{III}{ }_{2}\left(\mathrm{lt} \mathrm{s} \mathrm{s}^{1+2}\right)$ & $(-)$ & $(+)(4 w, 180$ colony $)$ & $(-)$ & N.D. \\
\hline & 3 & ${ }_{\mathrm{b}} \mathrm{III}_{2}\left(\mathrm{rt} \mathrm{S} \mathrm{S}^{2}, 1 \mathrm{t} \mathrm{S} \mathrm{S}^{1+2}\right)$ & G3 & $(+)(5 \mathrm{w}, 20$ colony $)$ & $(-)$ & N.D. \\
\hline & 4 & ${ }_{1} \mathrm{III}_{1}\left(\mathrm{lt} \mathrm{s} \mathrm{s}^{6}\right)$ & $(-)$ & $(+)(4 \mathrm{w}, 2$ colony $)$ & $(-)$ & $(+)$ \\
\hline \multirow{10}{*}{$\begin{array}{l}\text { April 1996 } \\
\text { March 2001 }\end{array}$} & 5 & $\mathrm{II}_{2}\left(\mathrm{rt} \mathrm{S}^{1}, \mathrm{~S}^{2}\right)$ & G3 & (+) (6w, 5 colony) & $(-)$ & N.D. \\
\hline & 6 & ${ }_{b} \mathrm{III}_{2}\left(\mathrm{rt} \mathrm{S} \mathrm{S}^{2}\right.$, lt $\left.\mathrm{S}^{1+2}\right)$ & $\mathrm{G} 2$ & (+) $(4 \mathrm{w}, 10$ colony $)$ & $(-)$ & N.D. \\
\hline & 7 & ${ }_{b} \mathrm{III}_{3}\left(\mathrm{rt} \mathrm{S}^{6}, S^{8}, \mathrm{~S}^{9}, \mathrm{~S}^{10}, \mathrm{It} \mathrm{S}^{8}, \mathrm{~S}^{9}, \mathrm{~S}^{10}\right)$ & G3 & $(+)(4 \mathrm{w}, 5$ colony $)$ & $(-)$ & N.D. \\
\hline & 8 & ${ }_{1} \mathrm{II}_{2}\left(\mathrm{lt} \mathrm{S}^{8}, \mathrm{~S}^{9}, \mathrm{~S}^{10}\right)$ & G1 & $(+)(6 \mathrm{w}, 6$ colony $)$ & $(-)$ & N.D. \\
\hline & 9 & $\mathrm{rII}_{2}\left(\mathrm{rt} \mathrm{S} \mathrm{S}^{7}, \mathrm{~S}^{8}, \mathrm{~S}^{9}, \mathrm{~S}^{10}\right)$ & G2 & $(+)(4 \mathrm{w}, 20$ colony $)$ & $(-)$ & N.D. \\
\hline & 10 & ${ }_{\mathrm{IIII}}\left(\mathrm{It} \mathrm{S} \mathrm{S}^{1+2}, \mathrm{~S}^{6}\right)$ & G2 & $(+)(6 \mathrm{w}, 12$ colony $)$ & $(-)$ & N.D. \\
\hline & 11 & ${ }_{b} \mathrm{III}_{2}\left(\mathrm{rt} \mathrm{S} \mathrm{S}^{6}, \mathrm{It} \mathrm{S}^{4}, \mathrm{~S}^{6}, \mathrm{~S}^{9}, \mathrm{~S}^{10}\right)$ & $\mathrm{G} 2$ & (+) (7w, 5 colony) & $(-)$ & N.D. \\
\hline & 12 & ${ }_{\mathrm{r}} \mathrm{III}_{2}\left(\mathrm{rt} \mathrm{S} \mathrm{S}^{1}, \mathrm{~S}^{2}\right)$ & $(-)$ & $(+)(4 \mathrm{w}, 7$ colony $)$ & $(-)$ & N.D. \\
\hline & 13 & ${ }_{\mathrm{r}} \mathrm{III}_{2}\left(\mathrm{rt} \mathrm{S}^{1}, \mathrm{~S}^{2}\right)$ & $(-)$ & $(+)(5 \mathrm{w}, 20$ colony $)$ & $(-)$ & N.D. \\
\hline & 14 & ${ }_{\mathrm{I}} \mathrm{II}_{1}\left(\mathrm{lt} \mathrm{S}^{6}\right)$ & $(-)$ & $(+)(4 \mathrm{w}, 10$ colony $)$ & $(-)$ & $(+)$ \\
\hline
\end{tabular}

N.D.: Not done.

\section{Discussion}

Although there have been several reports regarding the onset or worsening of tuberculosis following the administration of corticosteroid drugs (2-4), the mechanism has been considered to involve suppression of the killing activity of monocyte/ macrophages (5), a decrease in T lymphocytes (especially CD4 positive T lymphocytes 9 (6), or suppression of cytokine production such as that of interleukin-1 (7). Because the accurate morbidity of tuberculosis due to corticosteroid drugs is unknown clinically, we studied the number of patients who received corticosteroid drugs for over one month, and their underlying diseases. The morbidity of tuberculosis during administration of corticosteroid drugs slightly increased from 4 patients (1.4\%) between 1991 and 1996 to 10 patients (2.9\%) between 1996 and 2001. This difference, however, was not statistically significant. This figure was high compared to the morbidity of $0.7 \%$ for patients receiving corticosteroid drugs for bronchial asthma (8) and 1.0\% for patients given corticosteroid drugs for rheumatoid arthritis, collagen diseases or he- patic diseases (9). However, the increase was not so significant in the comparison of both periods even when the patients were separated into those with idiopathic pulmonary fibrosis and those with diabetes mellitus.

Regarding the reason why the morbidity for pulmonary tuberculosis was high, cellular immunoactivity decreases when corticosteroid drugs are administered at a dose of over $15 \mathrm{mg} /$ day for a few weeks. The morbidity of tuberculosis increases if administration of these drugs is continued for a longer period of time (1). We had 267 patients to whom more than $20 \mathrm{mg} /$ day of corticosteroid drugs were administered for over one month between April 1991 and March 1996 and 348 patients who received the same treatment between April 1996 and March 2001. The classification of these patients according to their underlying diseases showed that the number of underlying diseases for which corticosteroid drugs are being administered; e.g., bronchial asthma, interstitial pulmonary fibrosis, and collagen diseases, is increasing. The risk of appearance of tuberculosis existed in 267 patients from among total 6,102 inpatients (4.4\%) between 1991 and 1996, and in 348 from among a total 6,314 inpatients (5.5\%) between 1996 and 2001. How- 
Pulmonary Tuberculosis in Association with Corticosteroid Drugs

Table 6. Treatment and Outcome for Pulmonary Tuberculosis

\begin{tabular}{|c|c|c|c|c|}
\hline & Case & Antituberculous drug (Duration) & Corticosteroid & Outcome \\
\hline \multirow{4}{*}{$\begin{array}{l}\text { April 1991 } \\
\text { March } 1996\end{array}$} & 1 & $\begin{array}{l}\mathrm{INH}+\mathrm{RFP}+\mathrm{SM} \rightarrow \mathrm{INH}+\mathrm{RFP}+\mathrm{EB} \\
(3 \text { months }) \quad(9 \text { months })\end{array}$ & $15 \rightarrow 10 \mathrm{mg} /$ day & Conversion, Improved \\
\hline & 2 & N.D. & $15 \rightarrow 40 \mathrm{mg} /$ day & $\begin{array}{l}\text { Worsening of mycosis fungoides } \\
\text { Death before the initiation of treatment }\end{array}$ \\
\hline & 3 & INH+RFP+SM (3 weeks) & $20 \mathrm{mg} / \mathrm{day}$ & $\begin{array}{l}\text { Complicated pneumonia, Death } \\
\text { (cytomegalovirus,MRSA) ( } 3 \text { weeks later) }\end{array}$ \\
\hline & 4 & $\mathrm{INH}+\mathrm{RFP}+\mathrm{SM}$ (2 months) & $5 \mathrm{mg} /$ day & Conversion, Improved \\
\hline \multirow{10}{*}{$\begin{array}{l}\text { April 1996 } \\
\text { March } 2001\end{array}$} & 5 & $\mathrm{INH}+\mathrm{RFP}+\mathrm{SM}$ (6 months) & $7.5 \rightarrow 5 \mathrm{mg} / \mathrm{day}$ & Conversion, Improved \\
\hline & 6 & INH+RFP+EB (3 months) & $10 \mathrm{mg} /$ day & Conversion, Improved \\
\hline & 7 & $\begin{array}{l}\mathrm{INH}+\mathrm{RFP}+\mathrm{SM} \rightarrow \mathrm{INH}+\mathrm{RFP}+\mathrm{EB} \\
(3 \text { months }) \quad(3 \text { months })\end{array}$ & $10 \rightarrow 7.5 \rightarrow 5 \mathrm{mg} / \mathrm{day}$ & Conversion, Improved \\
\hline & 8 & INH+RFP+EB (6 months) & $5 \mathrm{mg} /$ day $\rightarrow$ stop & $\begin{array}{l}\text { Urinary tract infection } \rightarrow \text { Sepsis (E. faecalis) } \\
\text { Death (6 months later) }\end{array}$ \\
\hline & 9 & INH+RFP+EB (3 months) & $15 \rightarrow 10 \rightarrow 60 \mathrm{mg} /$ day & $\begin{array}{l}\text { Acute transformation of IIP } \\
\text { Deth ( } 4 \text { months later) }\end{array}$ \\
\hline & 10 & $\mathrm{INH}+\mathrm{RFP}+\mathrm{SM} \rightarrow \mathrm{INH}+\mathrm{RFP}+\mathrm{EB}$ & $30 \rightarrow 20 \rightarrow 15 \rightarrow 10 \mathrm{mg} /$ day & $\begin{array}{l}\text { Complicated pneumonia (MRSA) } \\
\text { Death ( } 6 \text { months later) }\end{array}$ \\
\hline & 11 & $\mathrm{INH}+\mathrm{RFP}+\mathrm{EB}$ (12 months) & $10 \mathrm{mg} /$ day & Conversion, Improved \\
\hline & 12 & $\begin{array}{l}\mathrm{INH}+\mathrm{RFP}+\mathrm{SM} \rightarrow \mathrm{INH}+\mathrm{RFP}+\mathrm{EB} \\
(3 \text { months }) \quad(9 \text { months })\end{array}$ & $10 \mathrm{mg} /$ day & Conversion, Improved \\
\hline & 13 & INH+RFP+EB (4 months) & $10 \rightarrow 40 \mathrm{mg} /$ day & $\begin{array}{l}\text { Acute transformation of IIP } \\
\text { Death ( } 3 \text { months later) }\end{array}$ \\
\hline & 14 & $\begin{array}{l}\mathrm{INH}+\mathrm{RFP}+\mathrm{SM} \rightarrow \mathrm{INH}+\mathrm{RFP}+\mathrm{EB} \\
(3 \text { months }) \quad(9 \text { months })\end{array}$ & $40 \rightarrow 30 \rightarrow 20 \rightarrow 10 \mathrm{mg} /$ day & Conversion, Improve \\
\hline
\end{tabular}

N.D.: Not done E. faecalis: Enterococcus faecalis, MRSA: Methicillin-resistant Staphylococcus aureus.

ever, no relationships between the initial dose, the interval of administration and the morbidity of tuberculosis were found in our study.

Because the clinical findings for pulmonary tuberculosis in association with corticosteroid therapy for a long period of time have been atypical, it has been emphasized that careful observation of the clinical course is important. This was apparent with our cases (10).

Since 6 of our 14 patients (42.9\%) had a history of tuberculosis and such patients are at a 10 -fold risk for developing pulmonary tuberculosis (11), it is possible that all of those patients would have developed pulmonary tuberculosis even if the total dose of corticosteroid drugs had been lower.
Regarding the method of detection, clinical symptoms were poor in 8 of our 14 patients, in whom the disease was detected by chest X-ray during follow-up of an underlying disease. Because it is difficult to detect the disease earlier from patient complaints, observation of the clinical course using periodic chest X-ray examination was important.

In addition, PPD was performed for 13 patients and was positive in 8 of those 13 patients (61.5\%). Among 10 patients for whom PPD was performed before the initiation of coreticosteroid drugs, six patients converted to positive, one patient converted to negative and three remained negative. These results were not so useful for the diagnosis of tuberculosis because cellular immune activity was decreased, being masked 
by the corticosteroid drugs.

As for the radiological findings, because the abnormal shadows of most the patients were recognized as infiltration opacities without cavity and the lesions were located in the lower lung field in four patients (28.6\%), atypical radiological findings cannot be considered to have masked an earlier diagnosis.

Regarding the microbiological examination for Mycobacterium tuberculosis, the smear positive rate of pulmonary tuberculosis during long-term administration of corticosteroid drugs has been reported to be over 50\% (12) in western countries. In our study, the smear positive rate was $57.1 \%$ and TBLB was performed for three patients who were smear negative on the microbiological examination. Histological findings also corresponded with those for tuberculosis in all patients. As a result, an earlier diagnosis could be made, but a big problem arose regarding nosocomial infections. None of the strains of cultured Mycobacterium tuberculosis had tolerance for all antituberculous drugs and there were no problems in the treatment of pulmonary tuberculosis. However, a patient with pulmonary tuberculosis due to INH tolerance Mycobacterium tuberculosis has been recently reported (1) and we believe caution regarding the tolerance for antituberculous drugs will be necessary hereafter.

Concerning treatment, the American Thoracic Society (ATS) has recommended INH preventive administration to all patients who are receiving corticosteroid drugs on a long-term basis and who are PPD positive (1). In our study, INH preventive administration was immediately carried out for only 2 of 14 patients for two months after the initiation of corticosteroid drugs, but the dose of INH was not sufficient to prevent the appearance of pulmonary tuberculosis appeared after the administration of INH was stopped. We could not determine the clinical effectiveness of INH preventive administration in this study.

Although we made a clinical analysis of patients with pulmonary tuberculosis in association with corticosteroid therapy of $20 \mathrm{mg} /$ day for over one month, we considered a periodic chest X-ray by a respiratory medicine specialist to be particularly important because the frequency of pulmonary tuberculosis in association with corticosteroid drugs transiently slightly increased from $1.4 \%$ to $2.9 \%$ among inpatients. Smear positive cases have been increasing. Finally, this condition has shown no clinical symptoms or atypical radiographic findings.

\section{References}

1) Bass JB, Farer LS, Hopewell PC, et al. American Thoracic Society Society Statement. Treatment of tuberculosis and tuberculosis infection in adults and children. Am J Respir Crit Care Med 149: 1359-1374, 1994.

2) Smyllite HC, Connolly CK. Incidence of serious complications of corticosteroid therapy in respiratory disease. A retrospective survey of patients in the Brompton Hospital. Thorax 23: 571-578, 1968.

3) Schatz M, Patterson R, Kloner R, Falk K. The prevalence of tuberculosis and positive tuberculin skin tests in a steroid-treated athmatic population. Ann Intern Med 84: 261-265, 1976.

4) Haanaes OC, Bergmann A. Tuberculosis emerging in patients treated with corticosteroids. Eur J Respir Dis 64: 294-297, 1983.

5) Schaffner A. Therapeutic concentrations of glucocorticoids suppress the antimicrobial activity of human macrophages without impairing their responsiveness to gamma interferon. J Clin Invest 76: 1755-1764, 1985.

6) Frey BM, Walker C, Frey FJ, de Weck AL. Pharmacokinetics and pharmacodynamics of three different predonisolone prodrugs: effect on circulating lymphocyte subsets and function. J Immunol 144: 2479-2487, 1984

7) Arya SK, Wong-Staal F, Gallo RC. Dexamethasone-mediated inhibition of human cell growth factor and gamma-interferon messenger RNA. Immunol 133: 273-276, 1984.

8) Kawai M. Corticosteroid drugs. Jpn J Thorac Dis 20: 1144-1155, 1982 (in Japanese, Abstract in English).

9) Fujimori I. Corticosteroid hormone therapy and infectious diseases. Sougou-Rinshou 23: 1758-1765, 1974 (in Japanese, Abstract in English).

10) Muto M, Sakurai N, Yamamoto K, et al. Clinical analysis of pulmonary tuberculosis with corticosteroid therapy. Kekkaku 60: 421-428, 1985 (in Japanese, Abstract in English).

11) Millar JW, Horne HW. Tuberculosis in immunosuppressed patients. Lancet 1: 1176-1178, 1979.

12) American Thoracic Society. Treatment of tuberculosis and other mycobacterial diseases. Am Rev Respir Dis 127: 791-796, 1983. 